\title{
Motivational trajectories for early language learning across the primary-secondary school transition
}

Article

Accepted Version

Graham, S., Courtney, L., Tonkyn, A. and Marinis, T. (2016) Motivational trajectories for early language learning across the primary-secondary school transition. British Educational Research Journal, 42 (4). pp. 682-702. ISSN 1469-3518 doi: https://doi.org/10.1002/berj.3230 Available at https://centaur.reading.ac.uk/50473/

It is advisable to refer to the publisher's version if you intend to cite from the work. See Guidance on citing.

To link to this article DOI: http://dx.doi.org/10.1002/berj.3230

Publisher: Wiley

All outputs in CentAUR are protected by Intellectual Property Rights law, including copyright law. Copyright and IPR is retained by the creators or other copyright holders. Terms and conditions for use of this material are defined in the End User Agreement.

www.reading.ac.uk/centaur 
Central Archive at the University of Reading

Reading's research outputs online 
Motivational trajectories for early language learning across the primary-secondary school transition

\author{
Suzanne Graham* \\ Louise Courtney \\ Alan Tonkyn \\ Theodoros Marinis
}

*corresponding author

s.j.graham@reading.ac.uk Tel: +44(0) 118378 2684; Fax: +44 (0) 1183782728

Institute of Education

University of Reading

London Road Campus

4 Redlands Road

Reading

RG1 5EX

UK 


\begin{abstract}
The transition from primary to secondary school is an area of concern across a range of curriculum subjects, and this is no less so for foreign language learning. Indeed problems with transition have been identified in England as an important barrier to the introduction of language learning to the primary school curriculum, with implications for learners' longerterm motivation for the subject. This longitudinal study investigated, through a questionnaire, the development of 233 learners' motivation for learning French in England, during the transition from primary to secondary schooling. It also explored whether levels and patterns of motivation differed according to the type of language teaching experienced, comparing a largely oracy-focused approach with one with greater emphasis on literacy activities.

Learners showed high and increasing levels of motivation across transition, placing particular value on learning French for travel. Being taught through an oracy or a literacy-focused approach had less impact on learners' motivation than broader classroom experiences, with the development of a sense of progress and feeling that instruction met their learning needs being especially important. A growing disjuncture emerged between valuing the learning of French for travel/communication and learners' low levels of self-efficacy for communication with native speakers, together with a desire for more communication-based activities. By the end of the first year of secondary school less positive attitudes towards learning French and less optimism about the possibility of future progress were beginning to emerge. The paper concludes by outlining the implications of the study for classroom practice in language learning.
\end{abstract}

Key words: transition; motivation; self-efficacy; early language learning. 


\section{Introduction}

The trajectory pattern of learners' motivation during schooling is an area of interest across subjects and in a range of contexts, particularly as there is evidence that motivation declines as learners pass through compulsory education (Wigfield, Eccles, MacIver, Reuman \& Midgley,1991). In England, changes in motivation for language learning are of particular concern, with low and declining levels contributing to limited uptake beyond the point at which language study is compulsory. The study of a foreign language became compulsory for all children in that country across both Key Stage 2 (KS2) (age 7-11) and Key Stage 3 (KS3) (age 11-14) in 2014, with the challenging expectation that learners will make significant progress in one language in KS2. The aim is that this will lay the foundations for, and develop positive attitudes towards, future learning in KS3 (DFE, 2013), , reflecting an assumption that young learners are necessarily motivated language learners. While many studies do indicate that, on average, across a range of countries, young learners hold highly positive views towards language learning (e.g. Cable et al., 2010; Nikolov, 1999), this is not universally the case, even in countries where the language being learnt is the 'global' language of English. For example, teachers of young learners in 142 countries surveyed by Copland, Garton and Burns (2014) reported concerns about how to motivate learners and convince them of the value of learning English.

In England, the likelihood of the primary modern languages initiative having a positive impact on learners' motivation for the subject at secondary school is perceived to be threatened by problems surrounding the transition between the two phases of education. Certain studies (e.g. Bolster, Balandier-Brown, \& Rea-Dickens, 2004), as well as more anecdotal evidence, suggest that language learning motivation declines with the move into secondary school. This phenomenon may arguably arise from the variability in the amount 
and quality of language teaching learners experience at primary school (likely to be greater than in other curriculum subjects), which then leads some secondary schools to feel obliged to start language instruction from scratch with all learners, regardless of what they have learnt previously (Office for Standards in Education, 2011), with implications for learners' sense of progress. Similar practices and problems for learners' motivation are also reported in the USA and Australia (Lo Bianco, 2009; Pufahl \& Rhodes, 2011). These and other classroom factors are likely to be particularly relevant for the development of learners' motivation in England, given the limited contact most children will have in the external environment with the languages taught at school (e.g. French, the most widely taught language in England). The extent to which teaching approaches and the broader classroom experience are related to young learners' motivational development has, however, received relatively little research attention. This article aims to fill that gap, reporting on a study of the development of motivation up to and over the period of transition for over 200 learners of French in England.

\section{Literature review}

We consider motivational trajectories firstly from a general education perspective, focusing in particular on the primary-secondary transition, on how changes in motivation may be explained theoretically, and drawing on empirical studies from different curriculum subject areas. We then consider key theoretical perspectives on foreign language learning in instructed settings, before turning to empirical studies of motivational development among younger language learners, especially across the primary-secondary age range. In that section we give particular attention to studies conducted in the context of England, given the very particular motivational issues influencing language learning in Anglophone contexts (Taylor \& Marsden, 2014). 
Many of the studies of motivational trajectories through and across different phases of education within a range of curriculum subjects have taken an expectancy-value perspective (e.g. first language English reading and writing in the US -Archambault, Eccles, \& Vida, 2010; mathematics and German as a first language in Germany- Spinath \& Steinmayr,2008). This perspective holds that motivation is influenced by a learner's sense of competence in a given domain (i.e. the expectation of being successful) and the value they attach to success in that area ('subjective task value', encompassing usefulness, interest, enjoyment and sense of importance, Wigfield \& Eccles, 2000). In addition, sense of competence and sense of value are believed to be closely related (Archambault et al., 2010). Furthermore, motivation development studies provide evidence of a dual decline in learners' sense of competence in, and sense of value for, different educational domains or subjects as they move from primary to secondary education. By about the age of 10, children become more aware of normative comparisons (in addition to experiencing more normative assessment once they start secondary school), develop skill in 'understanding and interpreting the evaluative feedback they receive', thus becoming 'more accurate or realistic in their self-assessments' and hence potentially more negative (Wigfield et al., 1997: 77). Learners' views of their ability to succeed in many subjects may therefore become more pessimistic with the change in school phase. Interestingly, however, Archambault et al. (2010), in their large 8-year longitudinal study of first language English reading and writing among 655 learners in the USA, found that for some learners, the move to secondary or junior high school led to an increase in sense of competence and sense of value in reading and writing, rather than to a decrease. They hypothesise that this improvement may have arisen from learners experiencing a different kind of English curriculum at the start of junior high school compared with what was experienced at elementary school, namely more literature study, which for some learners may have been of greater interest. This finding leads Archambault et al. (2010) to emphasise the 
importance of classroom experiences in relation to the 'trajectories of change' (p. 804) in learners' sense of competence and task value. Likewise, according to Spinath and Steinmayr (2008), learners' sense of efficacy and intrinsic motivation as they grow older may be positively influenced by 'perceptions of individual progress' and 'the optimism that competences can be developed' (p. 1567).

Sense of competence - self-efficacy (perception of one's ability to successfully complete a given task - Bandura, 1995), value, and optimism about future progress are equally important for motivation for second (L2) or foreign language learning. Indeed, studies of older secondary school language learners in England (i.e. 12-16 years of age) suggest that finding languages difficult and low self-efficacy regarding future success are key aspects of learners' decision to give up language study (Author 1; Erler \& Macaro, 2011). These factors seem to exert greater influence on learners' decision-making than any doubt in their minds about the 'importance' of language learning, contrary to popular views and those expressed in the UK media (Author 1). An influential view of L2 motivation, Dörnyei's (1994) framework, also identifies some important personal as well as classroom factors, which he sees as operating in a number of levels. These are: (1) the language level, comprising an 'integrative' element (for example, learning a language out of a desire to move closer to, or having interest in, the target language community) and an instrumental aspect (where a language is learnt for the external rewards and benefits it brings, e.g. increased employment prospects); (2) the learner level, including need for achievement and selfefficacy; and (3) the learning situation level, including the teacher and the course (e.g. the level of interest, satisfaction ). More recently, Dörnyei (2005) has developed the L2 Motivational Self System in which learners' motivation to learn a foreign language is held to be driven by the learner having an 'ideal self' image that includes the ability to speak a 
second language. While the relevance of the L2 Motivational Self System for young language learners has been questioned, in that their sense of self may not be sufficiently developed (Lamb, 2012), certain aspects are of interest. For example, Ryan and Dörnyei (2013) argue that to have a positive influence on motivation, 'self images must be plausible', i.e. achievable (p. 92).

The plausibility of becoming competent in the L2 may also be influenced by another aspect of Dörnyei‘s L2 Motivational Self System, the L2 Learning Experience, which includes 'both the immediate learning environment and learners' perceptions of their own previous language learning successes and failures' (Ryan \& Dörnyei, 2013: 91-92). While the importance of classroom experiences for language learning motivation has been studied fairly extensively among older learners, both within England (e.g. Taylor \& Marsden, 2012, 2014) and beyond (for example in China - see You \& Dörnyei, 2014), in early language learning contexts such studies are rarer. Nevertheless, these also indicate that classroom experiences have an impact on motivational trajectories. While instrumental motivation typically increases with age (Author 2), integrative motivation, and interest in foreign counties, by contrast, may be more susceptible to classroom factors. For example, Carreira (2006) attributes a decrease in interest in foreign countries among the Japanese Year 6 learners she studied to classroom experiences that did not give learners contact with the target language in real terms, preventing them from relating 'the English they learn in class to real communication' (p. 151).

Classroom experiences may also have an effect on motivation if they influence learners' perceptions of progress and competence especially around the time of primarysecondary transition, at a point when such a sense of competence becomes especially important for learners. For example, Carreira, Ozaki, and Maeda (2013) found that perceived L2 competence among young learners of English in Japan was more strongly related to 
motivation in Year 6 learners than it was for those in Years 3, 4 or 5 (in a cross-sectional study). In addition, this sense of L2 competence was related to teaching approaches that promoted a sense of learner autonomy (echoing the findings of an earlier study by $\mathrm{Wu}, 2003$, among young language learners in China). In England, a small-scale study by Bolster et al. (2004) found that learners were frustrated by secondary teachers' lack of recognition of their prior learning leading to repeated curriculum content and what they saw as the resulting negligible progress by the time they reached the second year of secondary school. By contrast, in a doctoral study of approximately 244 learners of French, Richardson (2014) suggests a more complex picture, with learners showing higher levels of enjoyment and selfefficacy for French at the start of secondary school than at the end of primary. Likewise, in another study of primary-secondary transition in England, Author 2 (date) found that 26 learners of French did not object to covering familiar content when they reached the first year of secondary school, as it enhanced their sense of making progress by consolidating their knowledge and skills. What did threaten their levels of motivation was that the focus of classroom activities seemed to be at odds with the learners' goals for language learning. High levels of motivation in Year 6 coincided with primary teaching consistent with learners' interest in languages as a means of communication. Learners attributed a dip in motivation at the start of secondary school to teaching that seemed to place more emphasis on accurate task completion (e.g. sentence-matching, copy writing) than on communication.. This suggests that any decline in motivation at transition is not just attributable to repeated content.

The interaction between learners' goals for language study, their sense of progress and their classroom experiences also emerges in a study by Lamb (2007), who, in a different context, traced the development of motivation in approximately 200 EFL learners in Indonesia during the first 20 months of English learning at junior high school, using questionnaires and interviews (the latter with a sub-sample of 12 learners). He found that 
learners became frustrated with slow progress and more negative about their performance in English and about the language learning experience, growing more focused on, and critical of, the classroom experience over time. Yet there was no change in how successful learners felt they would ultimately be in English; their sense of the importance of learning English also increased over time, probably because of the strong instrumental motivation to learn English in that context. Thus, while certain motivational variables remained constant (e.g. the importance of English, expectations of ultimate success), there was much greater fluctuation in classroom-related variables.

ef theAny investigation of the impact of classroom experiences on L2 motivation development among young learners should arguably include an exploration of the impact of contrasting teaching approaches experienced in the primary school. In England, while official curriculum guidance advocates a dual emphasis on the development of oracy and literacy skills (DfE, 2013; DfES, 2005), in practice, in recent years the oracy approach has been found to predominate (Cable et al., 2010), although it is unclear whether this will change with the new National Curriculum for languages published in 2013. From a motivational perspective, there is little research evidence to support a dual focus on oracy and literacy, although Johnstone (2008) argues that a focus on literacy skills boosts the motivation of young language learners, because it boosts overall attainment. By contrast Martin (2012) argues that an oracy focus leads to a greater sense of competence and hence to higher levels of motivation. To our knowledge, however, there has been no systematic investigation of whether adopting more of a literacy or more of an oracy focus does indeed impact differently on early language learning motivation.

From the review of the literature, it thus emerges that a sense of competence, value, and optimism about future progress is important for the motivational trajectory of language learners, alongside classroom experiences and especially the sense that these are aligned with 
learners' goals for language study. Yet it is also clear that to date we have a limited view of the nature of that trajectory within the context of primary-secondary transition in England, with only a few studies having been conducted, which also give a somewhat contradictory picture. Such studies have also tended to neglect the impact of teaching with differing pedagogical emphases on the development of learners' motivation. The present study was designed to fill that gap, by exploring the following questions:

1. What is the nature of motivation at the end of primary schooling and at the start of secondary? Does motivation change across transition?

2. To what extent is learners' level of motivation related to the pedagogical emphasis adopted by their teacher (Oracy vs Literacy) and the activities they experience?

\section{Method}

Research design

This investigation forms part of a larger, mainly quantitative longitudinal study, tracking learners of French from the end of Year 5 of primary school (third year of studying French, aged 9-10 years), to the end of Year 6, and into secondary school in Year 7 (halfway through the first term). A final round of data collection occurred at the end of Year 7. Part of the study focused on learners' linguistic development, tracked through a set of language tasks (available at http://pmlresearch.com). In addition, and to address Research Question 1, learners completed a motivation questionnaire, at the end of Year 6, and during the first and last term of Year 7. 
To address Research Question 2, two approaches were investigated, which differed in the emphasis placed on literacy development within the teaching of French. For simplicity and brevity these are referred to as 1) an Oracy approach, focusing primarily on speaking and listening, and 2) a Literacy approach, in which reading and writing activities are integrated into the teaching alongside oracy activities. School selection was based on responses to a questionnaire administered to schools in the South of England, where teachers were asked about the teaching activities they themselves used with Year 5 learners of French and their frequency, and which invited them to be involved in the full study. Nine schools accepted this invitation. The questionnaire items were created using the Key Stage 2 Framework for Languages, a non-statutory document that sets out objectives and related teaching activities in the areas of oracy and literacy, with different sets of objectives for years 3 to 6 of primary education in England (DfES, 2005). We used this as a source for oracy and literacy activities that teachers might be expected to use with learners (with space provided for teachers to add any activities not mentioned within the 15 literacy activities and 14 oracy activities listed). Alongside indicating frequency of use of different activities, teachers were also asked to state what proportion of lesson time was devoted to listening, speaking, reading and writing respectively.

For each of the nine schools willing to take part in the study, the percentage of literacy and oracy activities that teachers reported using every or most lessons was calculated. A literacy score was then allocated based on this percentage. Once the study was underway, lessons were also observed in each school with Year 6 learners (in some cases, a Year 5 class had been observed as well) using a lesson observation schedule. We reviewed activities observed in all lessons and cross-referenced them to the Key Stage 2 Framework objectives for Literacy to create a literacy scale from 1 (low) to 5 (high), to indicate the kinds of activities being used with Year 5 and 6 learners, as follows: 
1 = Year 3 reading activities used (e.g. recognise some familiar words in written form) but no writing activities

2 = Year 4 reading activities used (e.g. follow a short familiar text, listening and reading at the same time) but no writing activities

$3=$ Year $3 / 4$ reading activities + Year 3 writing activities used (e.g. writing of simple words)

$4=$ Year 5/6 reading activities used (e.g. reading short texts, understanding some detail from them) + Year 3/4 writing activities (e.g. writing of simple words and phrases using a model and some words from memory)

$5=$ Year 5/6 reading and writing activities used (e.g. write sentences on a range of topics using a model)

Hence a school receiving a score of 1 would only be including in Year 5 and 6 classes reading activities aimed at Year 3 learners.. We allocated more weight to writing as a literacy-based activity, as our previous observations, and research in the field (e.g. Cable et al, 2010; Ofsted, 2011) indicates that writing is less well-developed in primary classrooms than is reading, in spite of the potential added benefits of writing for language acquisition (Manchón, 2014). Where we also had a Year 5 lesson observation, we scored that lesson in the same way and took the mean of the two scores. The final observation score was then added to the questionnaire score, to give each school a total literacy score out of ten. Schools scoring over 6 were classed as Literacy, schools 6 and under as Oracy. We also looked at the amount of lesson time spent on oracy and literacy activities within the observed lessons to make judgements about borderline cases. This gave four schools in the Oracy group, and five in the Literacy group.

Schools were matched on key indicators including percentage of learners with Free School Meals entitlement (a measure of deprivation widely used in the UK), and percentage of 
pupils registered as having English as an Additional Language or Special Educational Needs. All schools were in the Department for Education's low percentage band for Free School Meals and SEN. All schools except one had low percentages of learners with English as an Additional Language (below 12\%; for one school, the figure was 27\%). Information was gathered through a teacher questionnaire about the amount of instruction given in French per week, and teachers' level of qualification in the French language and in teaching French. Learners received between 15 and 60 minutes a week of French instruction (70\% receiving the national average of 30-40 minutes). Seven teachers had high levels of French proficiency (i.e. were native speakers or had a French degree), one had a GCSE in French and another had no formal French qualification. Six teachers had completed a post-graduate qualification in language teaching (at either primary or secondary level), one had received some language pedagogy input in her general teaching qualification course, and two had had no training in language teaching.

\section{Learner Participants}

Questionnaire data were initially collected from 233 learners across the nine primary schools, although numbers of learners involved varied across time points, as indicated in Table 1 , especially as learners moved into Year 7. For the final questionnaire, four secondary schools were targeted where large numbers of participants were located, to maximise response rates and the effective use of resources. Primary school learners had been learning French since Year 3 and all received approximately two hours of French a week at secondary school, where they were taught in mixed ability groups

$<$ Table 1 here> 


\section{Instruments and procedures}

Questionnaire. A short questionnaire was designed to measure motivation for learning French. Motivation was conceptualised as a) general attitudes to learning French, including how much learners claimed to enjoy French lessons, whether they thought learning French is fun, important, helpful for getting a job, for travel abroad, and whether they were looking forward to studying it in the near future. Learners were also invited to comment in two openended items on what they had enjoyed the most and the least about French lessons. We were also interested in b) learners' self-efficacy for French, across a range of areas, both in the present time (i.e. how confident they felt to accomplish certain oracy and literacy language tasks), and how confident they were that they could complete a range of oracy and literacy tasks in the coming year at school, as well as how well they thought they would do overall in French the following year. It is important to note that self-efficacy refers to learners' perceptions of their ability to complete a certain task, rather than their actual ability.

The questionnaire was based on our reading of the second language motivation literature and designed to capture those aspects of motivation which seem most relevant to early instructed language learning. These include aspects of Dörnyei’s (1994) three level model - the language level (integrative and instrumental motivation), the learning situational level (interest, enjoyment), and the learner level (self-efficacy, expectancy). Items were also related to Wigfield and Eccles' (2000) work with a focus on ability beliefs (present), and expectancies of future success, and on value - usefulness, interest, enjoyment and importance.

The same closed item questions were asked at each time-point, with eight targeting current self-efficacy, five future self-efficacy, and five attitudes towards French learning (plus two open items). The final questionnaire at the end of Year 7 included two additional items: "Do you prefer how you learn French at secondary school or how you learnt French at 
primary school?" "If you could change anything about your Year 7 French lessons what would it be?" The questionnaire was piloted with a group of similar learners not involved in the study in order to ensure that all items were understandable by young learners. It was administered to all learners by a member of the research team in order to ensure consistency in how it was completed. Internal consistency was assessed through Cronbach's alpha for the questionnaire as a whole and for attitudes to learning French, current and future self-efficacy. The scales were highly consistent with alpha values ranging from .915 to .792 . The questionnaire for Year 7 is available at www.pmlresearch.com , with most items reproduced near-verbatim in the tables that are given in the 'Findings' section.

Ethical approval for the study was granted by the investigators' University, with informed consent from head teachers, parents/carers and from learners themselves.

\section{Data analysis}

Closed responses were converted to numerical form, 1-4 (e.g. 1 for disagree very much/not very well/Not much, 4 for agree very much/very well) to calculate means scores for our main measures (attitudes to learning French, current and future self-efficacy, then a total motivation score from these measures combined). The higher the mean score, the greater the positivity towards learning French. As the questionnaire data were ordinal and not normally distributed, between- and within-subject effects were explored through non-parametric tests (with a Bonferroni correction where multiple, unplanned comparisons were made).

The open-ended questionnaire responses were entered into Excel, reviewed by the first two authors and the main categories of responses extracted. The first author then coded all responses using these categories. This coding was then revisited by the first author a month later to check for intra-rater reliability, with a 95\% rate achieved. 


\section{Findings}

Research Question 1: Overall motivation, attitudes to language learning and self-efficacy trends over time

Considering mean scores for the sample as a whole (Table 2), and taking any score above 2.5 (the mean on a scale of 1-4) to indicate positivity towards learning French, then most aspects of motivation were high in Year 6 (apart from current self-efficacy) and became increasingly so at the start of Year 7 over the immediate period of transition from primary to secondary school, at a statistically significant level and with large effect sizes (Cohen, 1988). By the end of Year 7, however, while self-efficacy continued to increase, attitudes to language learning had declined from where they had been at the start of the year, at statistically significant levels (moderate effect size). Nevertheless, , all measures were significantly higher at the end of Year 7 than at the end of Year 6, with moderate to large effect sizes. On the other hand, Standard Deviations were high, with scores ranging from around 1 to 4 . Hence, within a generally well-motivated group of learners, there were a number with very low levels of motivation.

<Table 2 here>

Attitudes to learning French. An additional analysis of individual items making up attitudes to learning French was then undertaken (Table 3). In Year 6 there was a high level of agreement with the idea that French is important, not especially for employment purposes, but very much so for travel abroad. Indeed, $95 \%$ of learners agreed with the statement 'Learning French will help me if I want to travel abroad', suggesting that for these young learners, the strongest rationale for learning a language is to communicate with its speakers beyond the UK. This was true even for learners whose overall mean motivation score was very low, i.e. below 2 .

$<$ Table 3 here>

By the start of Year 7, mean values for all components of attitudes to learning French had improved. For most aspects the increase from Year 6 to Year 7 levels reached a statistically significant level, except for those which were already very high in Year 6, namely French is important and French is helpful for travel abroad. Hence these continued to 
be central aspects of learners' perception of the value of French study across the transition phase, French for travel abroad receiving almost total agreement from learners.

By the end of Year 7, all aspects of attitudes to learning French had declined in relation to where they were at the start of the year, except for 'Learning French will help me if I want to travel abroad', which remained at a constantly high level. In spite of the decreases observed, the majority of learners still expressed positive attitudes to learning French. As at all other time points, almost all learners perceived French to be important for travel and this continued to be the statement which attracted the highest level of agreement. Furthermore, at the end of Year 7 we also asked learners directly whether they preferred learning French at primary or at secondary school. The preference for secondary school learning was marked, $89 \%$ against $11 \%$ who preferred French at primary school.

Current self-efficacy. We also explored sub-components of each self-efficacy measure in more detail (Table 4). From Year 6 to the start of year 7 learners became more confident in all aspects of French, except for singing songs, where their confidence decreased, possibly because songs did not feature as much in their secondary school lessons as they had done at primary level. Changes from Year 6 to 7 were all statistically significant except for saying sentences and singing songs. There were fewer significant differences between the start and end of Year 7. Overall, Table 4 suggests that learners' self-efficacy mainly increased in the areas of saying sentences, reading and writing, the latter being the area in which they felt the most confident by the end of Year 7. This may reflect a growing emphasis on literacy skills at secondary school.

$<$ Table 4 here>

Future self-efficacy. When learners were asked about how well they felt they would do in French overall, and how well they felt they would be able to do certain things in French in the near future (i.e. in the coming school year), there was , some variation across time points, and for different aspects of their French. The mean score below 2.5 at the end of Year 6 is notable, with only $41 \%$ of children feeling they would do quite well or very well overall at French in Year 7. . This relative lack of confidence in future progress is also seen in the figures for being able to hold a conversation in the future 'with a real French person', where the mean score is low compared with that for the more monological 'Use lots of different words to talk about things that I do in my free time'. Conversational language was also the 
area of least confidence at the start of Year 7, at a point when future self-efficacy levels were generally high. This was also the case at the end of Year 7.

$<$ Table 5 here $>$

At the start of Year 7, learners' levels of future self-efficacy saw statistically significant increases across all sub-areas in comparison with Year 6 levels. Yet a more mixed picture emerged at the end of Year 7. While means had increased in all areas compared with the start of Year 7, in none of the areas was the increase significant, suggesting a stalling in expectations about future progress. In addition, the percentage of learners feeling they would do quite well or very well in the following year (i.e. in Year 8) had reduced from $78 \%$ to $46 \%$, perhaps indicating more measured and realistic expectations about overall future success.

\section{Research Question 2: motivation in relation to teaching approach}

We began by comparing mean scores for total motivation and its sub-components by oracy/literacy teaching approach at each time point (Table 6, Mann-Whitney U Tests). Scores were comparable across the Literacy and Oracy groups; while Oracy learners had significantly higher levels of current self-efficacy in Year 6, this difference was not maintained in Year 7 where both groups reported similar levels. There were, however, 38 learners in Year 6 with very low levels of total motivation, of whom 29 were in schools from the Literacy group.

$<$ Table 6 here>

To explore why Oracy learners had higher levels of current self-efficacy in Year 6, total self-efficacy scores for all oracy activities and literacy activities in the questionnaire were calculated in order to see whether Oracy learners had higher levels of self-efficacy for oral-based activities (saying sentences, singing songs, understanding the teacher), and Literacy learners for literacy-based activities (understanding a written passage, writing sentences, spelling words). While across the sample, all learners had higher levels of selfefficacy for oracy activities, there was no significant difference for either type of activity by teaching approach. In addition, for the learners with very low levels of motivation, no statistically significant differences regarding self-efficacy for different types of activities 
were found between the Oracy and Literacy groups, suggesting that approach had little or no impact on where these learners lacked confidence.

The possibility that levels of motivation were related to other teaching factors such as amount of instruction per week, the level of the teacher's French proficiency and training in teaching French were also explored through Mann-Whitney U tests. No statistically significant differences were found.

Classroom activities. Further insights into the relationship between the classroom experience and motivation were sought by examining the kinds of activities all learners said they had enjoyed or not enjoyed in the open-ended parts of the questionnaire, and in the reasons they gave for preferring French at secondary school. After the initial coding of comments, responses were quantified to identify the areas which were most frequently mentioned. Table 7 shows all categories of responses mentioned on more than ten occasions by learners at the end of Year 6, and on five or more occasions at the start and end of year 7 (when responses were more diverse). At the end of Year 6, and to a lesser degree at the start of Year 7, respondents often simply said they 'liked learning x topic', or learning particular French words, without specifying further the reason for this enjoyment. The frequent mention of games and songs in year 6 may reflect the type of activities learners commonly experienced at primary school; they were popular with learners nonetheless, and remained so at the start of Year 7. Learners clearly also enjoyed using language as part of a creative activity and also those activities which allowed them to learn more about the culture of the target language community or to engage in purposeful writing such as corresponding with French pupils. These preferences may be linked with their strong sense that learning French is important for travel abroad. Thus, learners enjoyed both oracy- and literacy-type activities.

$<$ Table 7 here>

More creative and cultural aspects of language learning are notable by their absence from Year 7 responses, suggesting that they did not form part of the learners' classroom experience at secondary school. Instead, an important category emerging from the Year 7 (1) responses is that of making more progress in French. For some learners this seemed to be associated with increased self-efficacy, as this example suggests: 'learning more French than I did in primary school and I'm able to understand a bit more'. Others mentioned liking more challenge - 'We learn things quicker than in primary school' - while others appreciated 
being able to build on what they had covered before and extend it. Finally, speaking and interacting were important activities for Year 7 learners.

In both year groups, most learners claimed there was nothing about their lessons that they had not enjoyed, reflecting the generally positive trends seen in the closed item questionnaire responses. In Year 6 there was however a strong dislike of what one learner called 'the endless repetition' and another '[doing] the same exercise more than twice to remember things - it gets boring'. This sense of 'slow progress', as another put it, is accompanied by a strong sense, from some learners, of difficulty. Difficulty was associated in several cases with lack of understanding - 'doing lessons when I don't know what they mean', as one learner put it. There was a clear link between lack of interest and sense of difficulty for at least one learner, who explained 'sometimes I think French gets a bit boring when I can't understand it'. Where reading and writing were mentioned as disliked activities, by and large this involved 'book work' as learners called it, or worksheets, rather than more communicative and purposeful literacy activities.

Very similar factors were mentioned by learners at the start of year 7 , although in a slightly different order: repetition, writing and difficulty. While some complained of work already covered at primary school and finding this unchallenging ('I didn't really like starting from scratch because we already knew it') others made comments such as 'they say some things that I don't understand and I get confused'. What both groups have in common, arguably, is a dislike of not making progress or of learning in a way that they feel does not help them make progress. This was also reflected in comments about writing, which tended to be contrasted with more engaging learning - what one learner called 'a lot of copying down instead of thinking'. Teacher factors alluded to in the comments, including the teacher's use of the target language in class, also largely revolved around concerns about difficulty: 'sometimes when the teacher explains in French and forgets to translate into English'. Thus, both literacy- and oracy-related activities could be perceived negatively by learners, with the way in which they were being implemented in the classroom seeming to influence learners' perceptions. Class factors mainly concerned other pupils disrupting learning. Overall, there was a strong sense of learners disliking elements that prevented them from learning in the way that they felt they should be learning.

This was also reflected in the responses given by a sub-sample of learners with very low levels of motivation at the end of Year 6. For activities not enjoyed, two dominant 
categories emerged: experiencing difficulty, and boredom/lack of variety. These categories were equally distributed over Oracy and Literacy schools. It was noted, however, that references to boredom were more often made by learners with high scores in the linguistic tasks, while learners with lower (often very low) scores tended to cite difficulty more often. This suggests a link between motivation and attainment, which indeed was observed as a significant correlation between scores on the linguistic tasks administered as part of the larger study and total motivation scores for the sample as a whole (Author 2, in press).

Nevetherless, no such correlation was found for the sub-sample of poorly motivated learners, many of whom had scores on linguistic tasks well above the mean.

At the end of Year 7, learners continued to show enjoyment of activities that led to appropriate learning, frequently mentioning liking the greater challenge of secondary school language learning, alongside continued appreciation of 'fun 'activities and group work. Disliked activities were very similar to those mentioned at the start of the year: writing (mainly copy-writing), tests and repetition of content. Although most learners (89\%) said they preferred secondary school language learning over their primary school experience, largely because it was more challenging, there were aspects they would like to change at secondary school: more fun/games (17), more speaking/interaction (10) and more group work (10).

\section{Discussion}

This study set out to investigate patterns of motivation for language learning across the primary to secondary schooling transition phase, and the extent to which the teaching approaches and activities learners experienced were related to levels of motivation. For the first question, the picture that emerged was somewhat different from what has been found in some previous studies, where motivation declines when learners reach secondary school after a high point at the end of primary school (e.g. Bolster et al., 2004). In our study, group mean total motivation scores increased at significant levels across the immediate point of transition, and by the end of Year 7, levels were still significantly higher than in Year 6. Furthermore, most learners at the end of Year 7 claimed they preferred language lessons at secondary school. It is important to acknowledge, however, that while numbers in Years 6 and the start 
of Year 7 were relatively stable and comparable with those in other studies of young language learners (e.g. Carriera et al, 2013), results for the end of Year 7 must be interpreted with caution because of the much reduced sample at that point.

Across all learners, and throughout the study, there was a strong sense of the importance of language learning, and especially for travel abroad. Nevertheless, by the end of Year 7, overall attitudes towards learning French had declined from levels at the beginning of the year, except in relation to travel abroad. Similarly, while there was a clear increase in current self-efficacy across all time-points, there was more variability for future self-efficacy, for which there were no significant increases between the start and end of Year 7, suggesting that by the end of that year learners' confidence about future progress was waning, and that they were beginning to lose 'the optimism that competences can be developed' (Spinath \& Steinmayr, 2008: 1567). This may reflect the greater sense of realism or pessimism that comes with age (Wigfield et al., 1997) and the more assessment-driven work in secondary school.

It may also reflect learners' classroom experiences, however.. Specifically, while there was no clear indication that learners' attitudes to, and self-efficacy for, learning French were related to receiving either an Oracy or a Literacy approach (Research Question 2), there was some evidence of a conflict between what learners valued about the learning of French, and what French lessons seemed to be equipping them to do. A sense of the value of language study for travel remained consistently very high across all three time points, leading us to conclude that for young learners, this is the main rationale for language study. Travel has been identified as important motivator in studies exploring the attitudes of older learners (Clément, Dörnyei, \& Noels,1994), especially in contexts where contact with native speakers of the target in the normal environment is fairly limited and where travel provides the main 
possibility of 'cross-cultural friendships' (Clément et al., 1994: 432) and communicating with speakers of the target language. This may also be the case for the young learners in our study, although it cannot of course be assumed that understanding the importance of language learning for travel is necessarily a motivation for studying a language. Such understanding, does, however, indicate a particular attitude to language learning. It should also be acknowledged that our sample was drawn from a relatively affluent area in the south of England, and that travel may be less relevant for learners in other contexts in that country. Nevertheless, the value of language learning for travel has also been reported in relation to young learners in other parts of the country and from different socio-economic backgrounds (e.g. Myles \& Mitchell, 2012).

Furthermore, at each time point, the area of learners' future self-efficacy with the lowest mean score was having a conversation with a real French person. If learners are uncertain as to whether they will be able to achieve competence in the area that seems to matter most to them, and one that is held to be an important rationale for language learning i.e. travel and hence communicating with native speakers, then it seems likely that this will undermine their overall motivation for language learning as such competence does not seem 'plausible' to them, echoing Ryan and Dörnyei (2013: 92) in relation to the Ideal Self. Findings from other studies at other key points in education in England support that suggestion. In a study of transition from compulsory to non-compulsory language learning at age 16, Author 1 (year) found that students were very conscious of a gap between their expected high examination grades and competence in holding a conversation in French. While achieving oral fluency during the school years may be an unrealistic expectation, and learners may in fact have a higher level of oral competence than they realise, such a disjuncture between what learners value and what they feel their language instruction equips them to do cannot be ignored. Similarly, in their study of 14-year-old language learners, Taylor and Marsden (2012) 
identified a strong link between enjoying languages, feeling competent in the language, and perceiving the relevance of language learning, with all three elements needed for learners to be motivated. The authors also comment that many learners were interested in the language they were learning, but that this was overshadowed by their sense of inability to communicate effectively in it, leaving them feeling 'vulnerable and 'intimidated' by 'a territory they perceive to be inaccessible' (p.23). Furthermore, the open-ended comments from our learners suggested they wanted teaching approaches that developed their communication skills. At the end of Year 7, the areas they would like to change in their secondary school learning were to have more fun/games, more speaking/interaction and more group work. Taylor and Marsden (2012) asked a similar question of the Year 9 learners in their study; remarkably, they listed almost exactly the same areas - more fun/interactive/engaging activities, and more group work as things that would improve their language lessons.

This indicates that the classroom experience is key to the promotion of high levels of motivation for language learning across the primary-secondary transition, and in a way that goes beyond secondary teachers being mindful of what has been covered at primary school, or adopting either a literacy or an oracy approach. Learners' motivation seemed to be negatively affected by activities which they felt did not allow them to learn effectively and to make continuing progress, particularly in those areas that seemed to matter the most to them. Thus, factors from the learning situational level interacted with those from the learner level (self-efficacy, expectancy), referring to Dörnyei's (1994) 3-level model. It is also possible, as Macaro (2008) argues, that allowing learners to make 'rapid and substantial progress' ( $\mathrm{p}$. 108 , italics in the original) by increasing greatly the amount of teaching time available in Year 7 for languages would go a long way in developing the competence they seem to value and in turn their motivation for language learning beyond the first year of secondary school. Echoing the argument of Author 2 (year), unless there is greater alignment 
between what learners see as the goals of language learning and what they experience in the classroom, it is likely that the decline in motivation beginning to emerge for our learners at the end of Year 7 will not be halted within the context of England and possibly elsewhere. This alignment seems to us to be just as important, if not more so, than whether secondary teachers repeat content already covered at primary school. By examining the interaction between different aspects of motivation and the classroom experience, and doing so from a longitudinal perspective, this study has contributed to a further understanding of the nature of motivation for foreign language learning, and of the challenges for classroom practice that need to be faced.

Funding acknowledgements: To be added after review

\section{REFERENCES}

Author 1 and Author 2

Archambault, I., Eccles, J.S. \& Vida, M.N. (2010) Ability self-concepts and subjective value in literacy: joint trajectories from grade 1 through 2, Journal of Educational Psychology, 102(4), 804-816. doi: 10.1037/a0021075

Bandura, A. (1995) Exercise of personal and collective efficacy in changing societies, in: A. Bandura, (Ed) Self-efficacy in changing societies (Cambridge, Cambridge University Press).

Bolster, A., Ballandier-Brown, C. \& Rea-Dickens, P. (2004) Young learners of 
modern foreign languages and their transition to the secondary phase: a lost opportunity?, Language Learning Journal, 30(1), 35-41. doi: $10.1080 / 09571730485200211$

Cable, C., Driscoll, P., Mitchell, R., Sing, S., Cremin, T., Earl, J., Eyres, I., Holmes, B., Martin, C. \& Heins, B. (2010) Language learning at Key Stage 2: a longitudinal study.( London, Department for Children, Schools and Families (DCSF Research Reports DCSF-RR198)).

Carreira, J.M. (2006) Motivation for learning English as a foreign language in Japanese elementary schools, JALT Journal, 28 (2), 135-158.

Carreirea, J.M., Ozaki,K. \& Maeda, T. (2013). Motivational model of English learning among elementary school students in Japan. System, 41, 706-719. doi: http://dx.doi.org/10.1016/j.system.2013.07.017

Clément, R., Dörnyei, Z. \& Noels, K. (1994) Motivation, self-confidence and group cohesion in the foreign language classroom, Language Learning, 44(3), 417-448. doi: 10.1111/j.1467-1770.1994.tb01113.x

Cohen, J. (1988). Statistical power analysis for the behavioral sciences (2nd ed.) (New Jersey, Lawrence Erlbaum)

Copland, F., Garton, S. \& Burns, A. (2014) Challenges in teaching English to young learners: global perspectives and local realities, TESOL Quarterly, 48 (4), 738-762. doi: $10.1002 /$ tesq. 148

Department for Education (2013) Languages programmes of study 
National Curriculum in England. Available online at:

https://www.gov.uk/government/publications/national-curriculum-in-englandlanguages-progammes-of-study (accessed 22 May 2015).

Department for Education and Skills (2005). Key Stage 2 framework for languages (Nottingham, DfES Publications).

Dörnyei, Z. (1994). Motivation and motivating in the foreign languages classroom, The Modern Language Journal, 78 (3), 273-284. doi: 10.1111/j.15404781.1994.tb02042.x

Dörnyei, Z. (2005) The psychology of the language learner: individual differences in second language acquisition (Mahwah, NJ, Lawrence Erlbaum).

Erler, L. \& Macaro, E. (2011) Decoding ability in French as a foreign language and language learning motivation, The Modern Language Journal, 95(4),496-518. doi: 10.1111/j.15404781.2011.01238.xLamb, M. (2007) The impact of school on EFL learning motivation: an Indonesian

case study, TESOL Quarterly, 41(4), 757-780. doi: 10.1002/j.15457249.2007.tb00102.x

Lamb, M. (2012) A self-system perspective on young adolescents' motivation to learn English in urban and rural settings, Language Learning, 62(4), 997-1023. doi: 10.1111/j.1467-9922.2012.00719.x

Lo Bianco, J. (2009) Second languages and Australian schooling. Australian Education Review, 54. Available online at: http://research.acer.edu.au/aer/8/ (accessed 22 May 2015). 
Macaro, E. (2008) The decline in language learning in England: Getting the facts right and getting real, Language Learning Journal, 36 (1), 101-108. doi:

\section{$10.1080 / 09571730801988595$}

Martin, C. (2012) Pupils' perceptions of foreign language learning in the primary school findings from the Key Stage 2 Language Learning Pathfinder evaluation., Education 3-13, 4, 343-362. doi: 10.1080/03004279.2012.691373.

Manchón, R.M. (2014) Learning and teaching writing in the foreign languages classroom: Fostering writing-to-learn approaches. In P. Driscoll, E. Macaro \& A.Swarbrick (Eds), Debates in modern languages education (Abingdon, UK, Routledge).

Myles, F., \& Mitchell, R. (2012) Learning French from ages 5, 7 and 11: an investigation into starting ages, rates and routes of learning amongst early foreign language learners: ESRC End of Award Report, RES-062-23-1545 (Swindon, ESRC).Nikolov, M. (1999) 'Why do you learn English?' 'Because my teacher is short.' A study of Hungarian children's foreign language learning motivation, Language Teaching Research, 3(1), 33-56. doi: $10.1177 / 136216889900300103$.

Ofsted (2011) Modern languages. Achievement and challenge 2007-2010. Available online at: $\quad$ http://www.ofsted.gov.uk/resources/modern-languages-achievement-andchallenge-2007-2010

Pufahl, I. \& Rhodes, N. C. (2011) Foreign language instruction in U.S. schools: results of a national survey of elementary and secondary schools, Foreign Language Annals, 44(2), 258-288. doi: 10.1111/j.1944-9720.2011.01130.x. 
Richardson, K. (2014) What can we learn from the pupils? Transition from KS2 to KS3. Paper presented at the Association for Language Learning (ALL) Language World Conference, University of Lancaster, 4 April.

Ryan, S., \& Dörnyei, Z. (2013) The long-term evolution of language motivation and the L2 self, in: A. Berndt (Ed), Fremdsprachen in der Perspektive lebenslangen Lernens (Frankfurt, Peter Lang).

Spinath, B. \& Steinmayr, R. (2008) Longitudinal analysis of intrinsic motivation and competence beliefs: is there a relation over time?, Child Development, 79(5), 15551569. doi:10.1111/j.1467-8624.2008.01205.x

Taylor, F. \& Marsden, E. J. (2012) Influencing the perceived relevance of Modern Foreign Languages in Year 9: an experimental intervention (Research report). Available online at: https://pure.york.ac.uk/portal/en/publications/influencing-the-perceived-relevanceof-modern-foreign-languages-in-year-9-an-experimental-intervention-researchreport(9dc8123a-2972-4591-ba12-70c2a51780de)/export.html (accessed 22 May 2015).

Taylor, F., \& Marsden, E.J. (2014) Perceptions, attitudes, and choosing to study foreign languages in England: an experimental intervention, The Modern Language Journal, 98(4), 902-920. doi: 10.1111/modl.12146

Wigfield, A. \& Eccles, J.S. (2000) Expectancy-value theory of achievement motivation, Contemporary Educational Psychology, 25, 68-81. doi: 10.1006/ceps.1999.1015.

Wigfield, A., Eccles, J., MacIver, D., Reuman, D. \& Midgley, C. (1991) Transitions at early adolescence: changes in children's domain-specific self-perceptions and general selfesteem across the transition to junior high school, Developmental Psychology, 27, 552565. doi: 10.1037/0012-1649.27.4.552. 
Wigfield, A., Eccles, J. S., Yoon, K. S., Harold, R. D., Arbreton, A., Freedman-Doan, K. \& Blumenfeld, P. C. (1997) Changes in children's competence beliefs and subjective task values across the elementary school years: a three-year study, Journal of Educational Psychology, 89, 451-469.

$\mathrm{Wu}, \mathrm{X}$. (2003) Intrinsic motivation and young language learners: the impact of the classroom environment. System, 31(4), 501-517. doi: 10.1016/j.system.2003.04.001

You, C. J., \& Dörnyei, Z. (2014) Language learning motivation in China: results of a largescale stratified survey,.Applied Linguistics. doi: 10.1093/applin/amu046 


\section{TABLES}

Table 1: Numbers of respondents to questionnaire by Year Group and teaching approach

\begin{tabular}{lcccccr}
\hline Approach & & Year 6 & Year 7 (1) & \multicolumn{2}{c}{ Year 7 (2) } \\
& & & & & & \\
& Male & 51 & Male & 41 & Male & 26 \\
& Female & 42 & Female & 31 & Female & 20 \\
& Total & 93 & Total & 72 & Total & 46 \\
& Male & 61 & Male & 35 & Male & 20 \\
\hline Literacy & Female & 79 & Female & 54 & Female & 33 \\
& Total & 140 & Total & 89 & Total & 53 \\
& & & & & & \\
\hline Totals & 233 & 161 & & 99 & \\
\hline
\end{tabular}


Table 2 Mean scores on motivation measures with Standard Deviations and results of Within-Subjects, Wilcoxon Matched-Pairs Signed-Ranks Tests

\begin{tabular}{|c|c|c|c|c|c|c|c|}
\hline Motivation measure & Mean & SD & Min. & Max. & $\mathrm{z}$ value & p value & Effect size \\
\hline Year $6(N=233)$ & \multicolumn{7}{|c|}{ Year 6 vs Y7(1) } \\
\hline Total motivation & 2.50 & .53 & 1.26 & 3.74 & 8.33 & $<.001 * *$ & .69 \\
\hline $\begin{array}{l}\text { Attitudes to language } \\
\text { learning }\end{array}$ & 2.61 & .57 & 1.17 & 4.00 & 8.19 & $<.001 * *$ & .67 \\
\hline Current self-efficacy & 2.40 & .65 & 1.00 & 3.75 & 6.61 & $<.001 * *$ & .55 \\
\hline Future self-efficacy & 2.51 & .61 & 1.00 & 4.00 & 6.65 & $<.001 * *$ & .56 \\
\hline Year $7(1)(\mathrm{N}=161)$ & \multicolumn{7}{|c|}{ Year 7 (1) vs Year 7 (2) } \\
\hline Total motivation & 2.85 & .45 & 1.26 & 3.79 & 1.20 & .230 & .39 \\
\hline $\begin{array}{l}\text { Attitudes to language } \\
\text { learning }\end{array}$ & 3.10 & .46 & 1.71 & 4.00 & 3.04 & $.002 *$ & .31 \\
\hline Current self-efficacy & 2.65 & .53 & 1.00 & 3.83 & 4.32 & $<.001 * *$ & .46 \\
\hline Future self-efficacy & 2.86 & .57 & 1.00 & 3.88 & 1.47 & .142 & .16 \\
\hline Year $7(2)(N=99)$ & \multicolumn{7}{|c|}{ Year 6 vs Year 7 (2) } \\
\hline Total motivation & 2.97 & .53 & 1.00 & 3.95 & 6.28 & $<.001 * *$ & .63 \\
\hline $\begin{array}{l}\text { Attitudes to language } \\
\text { learning }\end{array}$ & 2.97 & .61 & 1.00 & 4.00 & 4.18 & $<.001 * *$ & .44 \\
\hline Current self-efficacy & 2.95 & .63 & 1.00 & 4.00 & 6.52 & $<.001 * *$ & .67 \\
\hline Future self-efficacy & 3.01 & .58 & 1.00 & 4.00 & 5.51 & $<.001 * *$ & .59 \\
\hline
\end{tabular}

Note: ** Significant at $\leq .001 ; *$ significant at $\leq .01$. Where $\mathrm{p}$ values are in italics, this indicates a decrease; in all other cases, differences are in the opposite direction, i.e. there is an increase from the earlier to the later time-point. 
Table 3 Attitudes to learning French, by Year Group, mean responses (SD) and comparisons across time (Within-Subjects, Wilcoxon Matched-Pairs Signed-Ranks Test)

\begin{tabular}{|c|c|c|c|c|c|c|}
\hline Item & $\begin{array}{l}\text { Year } 6 \\
(N=233)\end{array}$ & $\begin{array}{l}\text { Year } 7(1) \\
(N=161)\end{array}$ & $\begin{array}{l}\text { Year } 7(2) \\
(N=99)\end{array}$ & $\begin{array}{l}\text { Year 6 vs } \\
\text { Y7(1) }\end{array}$ & $\begin{array}{l}\text { Y7(1) vs } \\
\text { Y7(2) }\end{array}$ & $\begin{array}{l}\text { Year } 6 \text { vs } \\
\text { Y7(2) }\end{array}$ \\
\hline $\begin{array}{l}\text { I have enjoyed French } \\
\text { lessons }\end{array}$ & $\begin{array}{l}2.29 \\
(.82)\end{array}$ & $\begin{array}{l}2.94 \\
(.74)\end{array}$ & $\begin{array}{l}2.87 \\
(.84)\end{array}$ & $\begin{array}{l}\mathrm{p}<.001 * \\
(\mathrm{z}=7.09)\end{array}$ & $\begin{array}{l}p=.03 \\
(\mathrm{z}=2.16)\end{array}$ & $\begin{array}{l}\mathrm{p}<.001 * \\
(\mathrm{z}=3.77)\end{array}$ \\
\hline $\begin{array}{l}\text { I am looking forward to } \\
\text { future French learning }\end{array}$ & $\begin{array}{l}2.24 \\
(.93)\end{array}$ & $\begin{array}{l}3.13 \\
(.68)\end{array}$ & $\begin{array}{l}3.06 \\
(.84)\end{array}$ & $\begin{array}{l}\mathrm{p}<.001^{*} \\
(\mathrm{z}=7.83)\end{array}$ & $\begin{array}{l}p=.10 \\
(\mathrm{z}=1.64)\end{array}$ & $\begin{array}{l}\mathrm{p}<.001^{*} \\
(\mathrm{z}=4.62)\end{array}$ \\
\hline $\begin{array}{l}\text { Learning French is } \\
\text { important }\end{array}$ & $\begin{array}{l}2.95 \\
(.73)\end{array}$ & $\begin{array}{l}3.09 \\
(.59)\end{array}$ & $\begin{array}{l}2.99 \\
(.79)\end{array}$ & $\begin{array}{l}\mathrm{p}=.051 \\
(\mathrm{z}=1.95)\end{array}$ & $\begin{array}{l}p=.16 \\
(\mathrm{z}=1.42)\end{array}$ & $\begin{array}{l}\mathrm{p}=.99 \\
(\mathrm{z}=.004)\end{array}$ \\
\hline Learning French is fun & $\begin{array}{l}2.49 \\
(.82\end{array}$ & $\begin{array}{l}3.03 \\
(.64)\end{array}$ & $\begin{array}{l}2.93 \\
(.78)\end{array}$ & $\begin{array}{l}\mathrm{p}<.001^{*} \\
(\mathrm{z}=6.37)\end{array}$ & $\begin{array}{l}p=.02 \\
(\mathrm{z}=2.43)\end{array}$ & $\begin{array}{l}\mathrm{p}=.004^{*} \\
(\mathrm{z}=2.86)\end{array}$ \\
\hline $\begin{array}{l}\text { Learning French will } \\
\text { help me get a good job }\end{array}$ & $\begin{array}{l}2.33 \\
(.82)\end{array}$ & $\begin{array}{l}2.75 \\
(.70)\end{array}$ & $\begin{array}{l}2.63 \\
(.83)\end{array}$ & $\begin{array}{l}\mathrm{p}<.001 * \\
(\mathrm{z}=5.33)\end{array}$ & $\begin{array}{l}p=.15 \\
(\mathrm{z}=1.43)\end{array}$ & $\begin{array}{l}\mathrm{p}=.009 * \\
(\mathrm{z}=2.60)\end{array}$ \\
\hline $\begin{array}{l}\text { Learning French will } \\
\text { help me if I want to } \\
\text { travel abroad }\end{array}$ & $\begin{array}{l}3.41 \\
(.59)\end{array}$ & $\begin{array}{l}3.55 \\
(.53)\end{array}$ & $\begin{array}{l}3.55 \\
(.60)\end{array}$ & $\begin{array}{l}\mathrm{p}=.074 \\
(\mathrm{z}=1.78)\end{array}$ & $\begin{array}{l}\mathrm{p}=.87 \\
(\mathrm{z}=.16)\end{array}$ & $\begin{array}{l}\mathrm{p}=.21 \\
(\mathrm{z}=1.26)\end{array}$ \\
\hline
\end{tabular}

*Significant at $\mathrm{p} \leq .008$ after Bonferroni correction. Where $\mathrm{p}$ values are in italics, this indicates a decrease; in all other cases, differences are in the opposite direction, i.e. there is an increase from the earlier to the later time-point. 
Table 4 Current self-efficacy for learning French, by Year Group, mean responses (SD) and comparisons of current self-efficacy levels across time (Within-Subjects, Wilcoxon MatchedPairs Signed-Ranks Test)

\begin{tabular}{|c|c|c|c|c|c|c|}
\hline Item & $\begin{array}{l}\text { Year } 6 \\
(N=233)\end{array}$ & $\begin{array}{l}\text { Year } 7 \\
(1) \\
(N=161)\end{array}$ & $\begin{array}{l}\text { Year } 7 \\
(2) \\
(\mathbf{N}=99) \\
\end{array}$ & $\begin{array}{l}\text { Year } 6 \text { vs } \\
\text { Y7(1) }\end{array}$ & $\begin{array}{l}\text { Y7(1) vs } \\
\text { Y7(2) }\end{array}$ & $\begin{array}{l}\text { Year } 6 \text { vs } \\
\text { Y7(2) }\end{array}$ \\
\hline $\begin{array}{l}\text { I can say some sentences } \\
\text { to describe myself }\end{array}$ & $\begin{array}{l}2.53 \\
(.92)\end{array}$ & $\begin{array}{l}2.73 \\
(.84)\end{array}$ & $\begin{array}{l}3.27 \\
(.78)\end{array}$ & $\begin{array}{l}\mathrm{p}=.012 \\
(\mathrm{z}=2.51)\end{array}$ & $\begin{array}{l}\mathrm{p}<.001 * \\
(\mathrm{z}=4.75)\end{array}$ & $\begin{array}{l}\mathrm{p}<.001^{*} \\
\left(\mathrm{z}=5.25^{)}\right.\end{array}$ \\
\hline $\begin{array}{l}\text { I can sing a song in } \\
\text { French }\end{array}$ & $\begin{array}{l}2.74 \\
(.98)\end{array}$ & $\begin{array}{l}2.49 \\
(.96)\end{array}$ & $\begin{array}{l}2.47 \\
(.99)\end{array}$ & $\begin{array}{l}p=.018 \\
(\mathrm{z}=2.36)\end{array}$ & $\begin{array}{l}p=.200 \\
(\mathrm{z}=1.28)\end{array}$ & $\begin{array}{l}p<.001^{*} \\
(\mathrm{z}=4.04)\end{array}$ \\
\hline $\begin{array}{l}\text { I can understand what } \\
\text { my teacher says to me in } \\
\text { French }\end{array}$ & $\begin{array}{l}2.33 \\
(.84)\end{array}$ & $\begin{array}{l}2.74 \\
(.83)\end{array}$ & $\begin{array}{l}2.95 \\
(.79)\end{array}$ & $\begin{array}{l}\mathrm{p}<.001^{*} \\
(\mathrm{z}=5.44)\end{array}$ & $\begin{array}{l}\mathrm{p}=.225 \\
(\mathrm{z}=1.21)\end{array}$ & $\begin{array}{l}\mathrm{p}<.001^{*} \\
\left(\mathrm{z}=5.44^{)}\right.\end{array}$ \\
\hline $\begin{array}{l}\text { I can write a few } \\
\text { sentences in French to } \\
\text { describe myself }\end{array}$ & $\begin{array}{l}2.28 \\
(.99)\end{array}$ & $\begin{array}{l}2.68 \\
(.93)\end{array}$ & $\begin{array}{l}3.31 \\
(.76)\end{array}$ & $\begin{array}{l}\mathrm{p}<.001^{*} \\
(\mathrm{z}=5.22)\end{array}$ & $\begin{array}{l}\mathrm{p}<.001^{*} \\
(\mathrm{z}=5.12)\end{array}$ & $\begin{array}{l}\mathrm{p}<.001^{*} \\
\left(\mathrm{z}=5.22^{)}\right.\end{array}$ \\
\hline $\begin{array}{l}\text { I can understand a short } \\
\text { passage in French that I } \\
\text { read to myself }\end{array}$ & $\begin{array}{l}2.09 \\
(.88)\end{array}$ & $\begin{array}{l}2.38 \\
(.85)\end{array}$ & $\begin{array}{l}2.95 \\
(.79)\end{array}$ & $\begin{array}{l}\mathrm{p}<.001^{*} \\
(\mathrm{z}=4.28)\end{array}$ & $\begin{array}{l}\mathrm{p}<.001 * \\
(\mathrm{z}=3.72)\end{array}$ & $\begin{array}{l}\mathrm{p}<.001^{*} \\
\left(\mathrm{z}=4.28^{)}\right.\end{array}$ \\
\hline $\begin{array}{l}\text { I can spell the French } \\
\text { words that I have learnt } \\
\text { at school }\end{array}$ & $\begin{array}{l}2.34 \\
(.95)\end{array}$ & $\begin{array}{l}2.80 \\
(.78)\end{array}$ & $\begin{array}{l}2.86 \\
(.90)\end{array}$ & $\begin{array}{l}\mathrm{p}<.001^{*} \\
(\mathrm{z}=5.89)\end{array}$ & $\begin{array}{l}\mathrm{p}=.584 \\
(\mathrm{z}=0.55)\end{array}$ & $\begin{array}{l}\mathrm{p}<.001^{*} \\
\left(\mathrm{z}=5.89^{)}\right.\end{array}$ \\
\hline $\begin{array}{l}\text { I know what order to put } \\
\text { the words in a sentence } \\
\text { in French }\end{array}$ & $\begin{array}{l}2.43 \\
(.93)\end{array}$ & $\begin{array}{l}2.73 \\
(.81)\end{array}$ & $\begin{array}{l}2.96 \\
(.94)\end{array}$ & $\begin{array}{l}\mathrm{p}<.001^{*} \\
(\mathrm{z}=4.16)\end{array}$ & $\begin{array}{l}\mathrm{p}=.045 \\
(\mathrm{z}=2.01)\end{array}$ & $\begin{array}{l}\mathrm{p}<.001^{*} \\
\left(\mathrm{z}=4.16^{6}\right.\end{array}$ \\
\hline $\begin{array}{l}\text { I know whether a word is } \\
\text { masculine or feminine }\end{array}$ & $\begin{array}{l}2.45 \\
(.99)\end{array}$ & $\begin{array}{l}2.59 \\
(.97)\end{array}$ & $\begin{array}{l}2.86 \\
(.94)\end{array}$ & $\begin{array}{l}\mathrm{p}=.005^{*} \\
(\mathrm{z}=2.82)\end{array}$ & $\begin{array}{l}\mathrm{p}=.023 \\
(\mathrm{z}=2.27)\end{array}$ & $\begin{array}{l}\mathrm{p}=.005^{*} \\
\left(\mathrm{z}=2.82^{)}\right.\end{array}$ \\
\hline
\end{tabular}

*Significant at $\mathrm{p} \leq .0063$ after Bonferroni correction. Where $\mathrm{p}$ values are in italics, this indicates a decrease; in all other cases, differences are in the opposite direction, i.e. there is an increase from the earlier time-point. 
Table 5 Future self-efficacy for learning French, by Year Group, mean responses (SD) and comparisons of current self-efficacy levels across time (Within-Subjects, Wilcoxon MatchedPairs Signed-Ranks Test)

\begin{tabular}{|c|c|c|c|c|c|c|}
\hline Item & $\begin{array}{l}\text { Year } 6 \\
(\mathrm{~N}=\mathbf{2 3 3})\end{array}$ & $\begin{array}{l}\text { Year } 7(1) \\
(N=161)\end{array}$ & $\begin{array}{l}\text { Year } 7(2) \\
(\mathrm{N}=99)\end{array}$ & $\begin{array}{l}\text { Year 6 vs } \\
\text { Y7(1) }\end{array}$ & $\begin{array}{l}\text { Y7(1) vs } \\
\text { Y7(2) }\end{array}$ & $\begin{array}{l}\text { Year } 6 \text { vs } \\
\text { Y7(2) }\end{array}$ \\
\hline $\begin{array}{l}\text { How well do you } \\
\text { think you will do in } \\
\text { French in the coming } \\
\text { year? }\end{array}$ & $(.80)$ & $(.73)$ & $(.78)$ & $(\mathrm{z}=7.25)$ & $(\mathrm{z}=.90)$ & $(z=5.15)$ \\
\hline $\begin{array}{l}\text { Use lots of different } \\
\text { words to talk about } \\
\text { things I do in my free } \\
\text { time }\end{array}$ & $(.70)$ & $(.55)$ & (.63) & $(\mathrm{z}=5.16)$ & $(z=2.03)$ & $\left(\mathrm{z}=4.81^{)}\right.$ \\
\hline $\begin{array}{l}\text { Write in French } \\
\text { without making too } \\
\text { many mistakes }\end{array}$ & 2.63 & 2.95 & 3.09 & $\begin{array}{l}\mathrm{p}<.001 * \\
(\mathrm{z}=3.80)\end{array}$ & $\begin{array}{l}\mathrm{p}=.326 \\
(\mathrm{z}=.98)\end{array}$ & $\begin{array}{l}\mathrm{p}<.001^{*} \\
\left(\mathrm{z}=.82^{)}\right.\end{array}$ \\
\hline $\begin{array}{l}\text { Have a conversation } \\
\text { with a real French } \\
\text { person }\end{array}$ & 2.38 & 2.64 & 2.80 & $(\mathrm{z}=3.28)$ & $(z=.56)$ & $(z=3.46)$ \\
\hline $\begin{array}{l}\text { Read a short letter } \\
\text { from a French boy or } \\
\text { girl and understand } \\
\text { what it is about }\end{array}$ & $(.87)$ & $(.73)$ & $(.79)$ & $(\mathrm{z}=3.92)$ & $(\mathrm{z}=.27)$ & $\left(\mathrm{z}=2.05^{)}\right.$ \\
\hline
\end{tabular}

*Significant $\mathrm{p} \leq .01$ after Bonferroni correction 
Table 6 Means (Standard Deviations) by Teaching Approach and results of Between-Groups, Mann-Whitney U Tests.

\begin{tabular}{|c|c|c|c|c|c|c|c|c|c|}
\hline \multirow[t]{2}{*}{ Scale } & \multicolumn{3}{|l|}{ Y6 } & \multicolumn{3}{|l|}{ Y7(1) } & \multicolumn{3}{|l|}{ Y7(2) } \\
\hline & $\begin{array}{l}\text { Litera } \\
\text { cy } \\
\text { Mean } \\
\text { (SD) }\end{array}$ & $\begin{array}{l}\text { Orac } \\
\text { y } \\
\text { Mea } \\
\text { n } \\
\text { (SD) }\end{array}$ & $\begin{array}{l}\text { Mann } \\
\text { Whitne } \\
\text { y U }\end{array}$ & $\begin{array}{l}\text { Litera } \\
\text { cy } \\
\text { Mean } \\
\text { (SD) }\end{array}$ & $\begin{array}{l}\text { Orac } \\
\text { y } \\
\text { Mea } \\
\text { n } \\
\text { (SD) }\end{array}$ & $\begin{array}{l}\text { Mann } \\
\text { Whitne } \\
\text { y U }\end{array}$ & $\begin{array}{l}\text { Litera } \\
\text { cy } \\
\text { Mean } \\
\text { (SD) }\end{array}$ & $\begin{array}{l}\text { Orac } \\
\text { y } \\
\text { Mea } \\
\text { n } \\
\text { (SD) }\end{array}$ & $\begin{array}{l}\text { Mann } \\
\text { Whitne } \\
\text { y U }\end{array}$ \\
\hline $\begin{array}{l}\text { Total } \\
\text { motivati } \\
\text { on }\end{array}$ & $\begin{array}{l}2.45 \\
(.56)\end{array}$ & $\begin{array}{l}2.55 \\
(.49)\end{array}$ & $\begin{array}{l}\mathrm{u}=585 \\
\mathrm{p}=.19\end{array}$ & $\begin{array}{l}2.83 \\
(.45)\end{array}$ & $\begin{array}{l}2.86 \\
(.45)\end{array}$ & $\begin{array}{l}u=309 \\
p=.61\end{array}$ & $\begin{array}{l}3.0 \\
(.48)\end{array}$ & $\begin{array}{l}2.94 \\
(.59)\end{array}$ & $\begin{array}{l}u=1140 \\
.5 \\
p=.58\end{array}$ \\
\hline $\begin{array}{l}\text { Attitude } \\
\text { s to } \\
\text { learning } \\
\text { French }\end{array}$ & $\begin{array}{l}2.61 \\
(.60)\end{array}$ & $\begin{array}{l}2.60 \\
(.54)\end{array}$ & $\begin{array}{l}\mathrm{u}=6455 \\
\mathrm{p}=.91\end{array}$ & $\begin{array}{l}3.06 \\
(.49)\end{array}$ & $\begin{array}{l}3.08 \\
(.42)\end{array}$ & $\begin{array}{l}\mathrm{u}=3132 \\
.5 \\
\mathrm{p}=.69\end{array}$ & $\begin{array}{l}3.06 \\
(.59)\end{array}$ & $\begin{array}{l}2.88 \\
(.64)\end{array}$ & $\begin{array}{l}\mathrm{u}=1022 \\
\mathrm{p}=.17\end{array}$ \\
\hline $\begin{array}{l}\text { Current } \\
\text { Self- } \\
\text { Efficacy }\end{array}$ & $\begin{array}{l}2.32 \\
(.66)\end{array}$ & $\begin{array}{l}2.52 \\
(.62)\end{array}$ & $\begin{array}{l}\mathrm{u}=5369 \\
.5 \\
\mathrm{p}=.02 *\end{array}$ & $\begin{array}{l}2.6 \\
(.55)\end{array}$ & $\begin{array}{l}2.69 \\
(.62)\end{array}$ & $\begin{array}{l}\mathrm{u}=2971 \\
.5 \\
\mathrm{p}=.35\end{array}$ & $\begin{array}{l}2.92 \\
(.58)\end{array}$ & $\begin{array}{l}2.99 \\
(.69)\end{array}$ & $\begin{array}{l}\mathrm{u}=1109 \\
.5 \\
\mathrm{p}=.44\end{array}$ \\
\hline $\begin{array}{l}\text { Future } \\
\text { Self- } \\
\text { Efficacy }\end{array}$ & $\begin{array}{l}2.49 \\
(.65)\end{array}$ & $\begin{array}{l}2.54 \\
(.56)\end{array}$ & $\begin{array}{l}u=6260 \\
.5 \\
p=.62\end{array}$ & $\begin{array}{l}2.87 \\
(.51)\end{array}$ & $\begin{array}{l}2.84 \\
(.50)\end{array}$ & $\begin{array}{l}\mathrm{u}=3040 \\
\mathrm{p}=.55\end{array}$ & $\begin{array}{l}3.08 \\
(.51)\end{array}$ & $\begin{array}{l}2.93 \\
(.66)\end{array}$ & $\begin{array}{l}u=1069 \\
.5 \\
p=.29\end{array}$ \\
\hline
\end{tabular}

*Significant at $\mathrm{p} \leq .05$ 
Table 7

Open-ended responses: activities enjoyed and not enjoyed (number of times mentioned)

\begin{tabular}{llllll}
\hline \multicolumn{2}{c}{ Enjoyed } & & & Didn't enjoy \\
\hline Year 6 & Year 7 (1) & Year 7 (2) & Year 6 & Year 7 (1) & Year 7 (2) \\
\hline $\begin{array}{l}\text { Learning/ specific } \\
\text { topics (84) }\end{array}$ & $\begin{array}{l}\text { Learning/specific } \\
\text { topics (42) }\end{array}$ & Progress/challenge (46) Nothing (49) & Nothing (62) & Writing (25) \\
Games/fun (68) & Games/fun (38) & $\begin{array}{l}\text { Learning/specific } \\
\text { topics (44) }\end{array}$ & Repetition (41) & Writing (19) & Tests (8) \\
Songs (45) & $\begin{array}{l}\text { Progress/challenge } \\
\text { (27) }\end{array}$ & Games/fun (41) & Difficulty (33) & Repetition (17) & Repetition (7) \\
Treativity (34) & $\begin{array}{l}\text { Teacher factors (25) } \\
\text { Gultural aspects (25) }\end{array}$ & $\begin{array}{l}\text { Group work (13) } \\
\text { group work (17) }\end{array}$ & Writing (30) & Difficulty (14)
\end{tabular}


Technology (22)

Writing (14)
Speaking (14)

Songs (16)

Speaking (13)

Reading (12)

\section{Class factors (7)}

Tests (6) 